\title{
MSMB wt Allele
}

National Cancer Institute

\section{Source}

National Cancer Institute. MSMB wt Allele. NCI Thesaurus. Code C51285.

Human MSMB wild-type allele is located in the vicinity of $10 q 11.2$ and is approximately 13 $\mathrm{kb}$ in length. This allele, which encodes beta-microseminoprotein protein, may play a role in the modulation of autocrine paracrine factor in reproductive tissues, however a specific function has not been elucidated. 